\title{
Studies on Sex-Organ Development
}

\section{CHANGES IN CHROMATIN STRUCTURE DURING SPERMATOGENESIS IN MATURING ROOSTER TESTIS AS DEMONSTRATED BY THE INITIATION PATTERN OF RIBONUCLEIC ACID SYNTHESIS IN VITRO}

\author{
By CRISTOBAL MEZQUITA and CHING SUNG TENG \\ Department of Cell Biology, Baylor College of Medicine, Houston, TX 77030, U.S.A.
}

(Received 18 April 1977)

\begin{abstract}
To probe the structural change in the genome of the differentiating germ cell of the maturing rooster testis, the chromatin from nuclei at various stages of differentiation were transcribed with prokaryotic RNA polymerase from Escherichia coli or with eukaryotic RNA polymerase II from wheat germ. The transcription was performed under conditions of blockage of RNA chain reinitiation in vitro with rifampicin or rifamycin AF/013. With the $E$. coli enzyme, the changes in (1) the titration curve for the enzyme-chromatin interaction, (2) the number of initiation sites, (3) the rate of elongation of RNA chains, and (4) the kinetics of the formation of stable initiation complexes revealed the unmasking of DNA in elongated spermatids and the masking of DNA in spermatozoa. In both cases the stability of the DNA duplex in the initiation region for RNA synthesis greatly increased. In contrast with the $E$. coli enzyme, the wheat-germ RNA polymerase II was relatively inefficient at transcribing chromatin of elongated spermatids. Such behaviour can be predicted if unmasked double-stranded DNA is present in elongated spermatids.
\end{abstract}

Spermatids undergoing differentiation possess chromatin with unique properties compared with previous stages of spermatogenesis: (1) non-histone proteins and acetylated histones are removed and replaced by phosphorylated protamines (Platz et al., 1975; Candido \& Dixon, 1972; Grimes et al., 1975; Mezquita \& Teng, 1977); (2) the euchromatic and heterochromatic regions of the chromatin are replaced by fibres of uniform appearance (Walker, 1971; Tingari, 1973; Chevaillier \& Gusse, 1975; Subirana, 1975); the beaded chromatin fibres are replaced by smooth fibres (Kierszenbaum \& Tres, 1975); (3) the unmasking of DNA is revealed by the high capacity for binding of actinomycin $D$ and cationic dyes (Lison, 1955; Loir \& Hocherau de Reviers, 1972; Barcellona et al., 1974; Mezquita \& Teng, 1977) and by the high template capacity for RNA synthesis in the presence of Escherichia coli RNA polymerase in vitro (Mezquita \& Teng, 1977); (4) the chromatin of differentiating spermatids is unable to support RNA synthesis in vivo (Monesi, 1964; Loir, 1972; Kierszenbaum \& Tres, 1975; Mezquita \& Teng, 1977).

At the end of spermatogenesis a massive condensation of the chromatin occurs. The DNA-protamine complex shows a degree of condensation similar to that found in the bacteriophage head and possesses low capacity for binding of actinomycin $D$ and cationic dyes (Olins et al., 1968; Darżynkiewicz et al., 1969; Loir \& Hochereau de Reviers, 1972; Mezquita
\& Teng, 1977). The nucleoprotamine is inactive in RNA synthesis in vivo and in vitro (Marushige \& Dixon, 1969; Premkumar \& Bhargava, 1972). All these observations indicate that a drastic rearrangement in chemical compositions and a change in structure are taking place in the genome. Since most of the information accumulated at present has been obtained with the electron microscope and by cytochemical methods, it is important to investigate the structural changes of the chromatin during spermatogenesis by using biochemical techniques. The deoxyribonucleases capable of specific interaction with the nucleoprotein complexes have been used as the tool for this purpose (Honda et al., 1974). The prokaryotic and eukaryotic RNA polymerases, despite the possibility of 'unfaithful' initiations when added exogenously to chromatin, could also serve as a tool for probing the major changes in chromatin structure (Yamamoto \& Alberts, 1976; Hirose et al., 1976; Tsai et al., 1976b). The technique of rifampicin (or rifamycin AF/013)-competition assay, developed by Sippel \& Hartmann (1970) and Mangel \& Chamberlin (1974) and subsequently adapted for the study of the initiation of RNA synthesis on chromatin (Tsai et al., 1975, 1976a; Schwartz et al., 1975), has been applied in the present study. This technique provided us with information on the structural changes of the chromatin during the transition from nucleohistone to nucleoprotamine in rooster spermatogenesis.

Vol. 170 


\section{Materials and Methods}

\section{Animals and chemicals}

Sexually maturing white Leghorn roosters (25-50 weeks old) were obtained from Hendricks Grain Farms, Houston, TX, U.S.A., and were used throughout this study.

The following chemicals were obtained from the sources indicated: $\left[{ }^{3} \mathrm{H}\right]$ UTP (specific radioactivity $17 \mathrm{Ci} / \mathrm{mmol}$ ), Tris and sucrose (ribonuclease-free) were from Schwarz/Mann (Orangeburg, NY, U.S.A.); EDTA, diphenylamine and ammonium sulphate were from Mallinckrodt (St. Louis, MO, U.S.A.); nucleoside 5'-triphosphates, heparin, tRNA (yeast), rifampicin and calf thymus DNA were from Sigma Chemical Co. (St. Louis, MO, U.S.A.); exponential-phase Escherichia coli (K12) paste was from Grain Processing Co. (Muscating, IO, U.S.A.); Proteinase $\mathrm{K}$ was from EM Laboratories (Elmsford, NY, U.S.A.); raw wheat germ was from General Mills (Kansas City, MO, U.S.A.); Polymin P was kindly given by BASF, Ludwigshafen, Germany; rifamycin AF/013 was a gift from Dr. G. Lancini (Gruppo Lepetit, Milano, Italy). All other chemicals were of analytical grade.

\section{Preparation of nuclei and chromatin}

The procedures for these preparations were as described by Mezquita \& Teng (1977); all the subsequent processes were done at $0^{\circ} \mathrm{C}$. Nuclei from the testis and from the spermatozoa of the vas deferens were isolated by the citric acid procedure and separated by centrifugation through a discontinuous sucrose density gradient and by sedimentation at unit gravity.

Five different fractions of nuclei were obtained: tetraploid primary spermatocytes (stage 1); small primary spermatocytes, secondary spermatocytes and spermatogonia cells (stage 2); round and elongating spermatids (stage 3 ); elongated spermatids and testicular spermatozoa (stage 4); spermatozoa from the vas deferens (stage 5). Chromatin from the different fractions of nuclei was prepared by stepwise decrease in ionic strength and suspended in $0.002 \mathrm{M}$ Tris/ $\mathrm{HCl}, \mathrm{pH} 7.5$, before use.

\section{Isolation of RNA polymerases}

$E$. coli RNA polymerase containing the $\sigma$-subunit was isolated and assayed as described by Burgess \& Jendrisak (1975). The final enzyme preparation was precipitated with $60 \%$-satd. $\left(\mathrm{NH}_{4}\right)_{2} \mathrm{SO}_{4}$ and stored at $-70^{\circ} \mathrm{C}$ in the storage buffer $[0.01 \mathrm{M}$-Tris $/ \mathrm{HCl}$, pH 7.9, $0.01 \mathrm{M}-\mathrm{MgCl}_{2}, 0.1 \mathrm{~mm}$-EDTA, $0.5 \mathrm{mM}$-dithiothreitol and $50 \%(\mathrm{v} / \mathrm{v})$ glycerol] at a concentration of $17 \mathrm{mg} / \mathrm{ml}$. The $E$. coli RNA polymerase was assayed with calf thymus DNA as a template, and the enzyme specific activity was 1000 units/mg of protein.
Wheat-germ RNA polymerase II was prepared and assayed as described by Jendrisak \& Burgess (1975). The enzyme eluted from the phosphocellulose column was precipitated with $\left(\mathrm{NH}_{4}\right)_{2} \mathrm{SO}_{4} \quad(50 \%$ saturation) and stored at $-70^{\circ} \mathrm{C}$ in the same buffer used for the $E$. coli enzyme but also containing $2 \mathrm{mg}$ of bovine serum albumin $/ \mathrm{ml}$. The enzyme specific activity assayed with single-stranded calf thymus DNA was 500 units/mg of protein.

\section{Conditions for RNA synthesis without reinitiation}

Chromatin ( $5 \mu \mathrm{g}$ as DNA) was preincubated with $E$. coli RNA polymerase (diluted with $1 \mathrm{mg}$ of bovine serum albumin $/ \mathrm{ml}$ ) at $37^{\circ} \mathrm{C}$ for $15 \mathrm{~min}$ in a preincubation buffer of $0.2 \mathrm{ml}$ final volume, containing $12.5 \mu \mathrm{mol}$ of Tris $/ \mathrm{HCl}$ buffer, $\mathrm{pH} 7.9,0.25 \mu \mathrm{mol}$ of $\mathrm{MnCl}_{2}, 12.5 \mu \mathrm{mol}$ of $\left(\mathrm{NH}_{4}\right)_{2} \mathrm{SO}_{4}$ and $0.50 \mu \mathrm{mol}$ of 2-mercaptoethanol. At the end of the preincubation period, RNA synthesis was started by the addition of $37.5 \mathrm{nmol}$ of ATP, GTP, CTP and $\left[{ }^{3} \mathrm{H}\right]$ UTP (75 c.p.m./pmol) in $0.05 \mathrm{ml}$ and incubated at $37^{\circ} \mathrm{C}$ for $15 \mathrm{~min}$. Rifampicin $(10 \mu \mathrm{g})$ and heparin $(200 \mu \mathrm{g})$ were added together with nucleotides.

Wheat-germ RNA polymerase II was preincubated with $5 \mu \mathrm{g}$ of chromatin at $37^{\circ} \mathrm{C}$ for $15 \mathrm{~min}$ in $200 \mu \mathrm{l}$ of preincubation buffer as described above. RNA synthesis was initiated by the addition of $50 \mu 1$ of a mixture containing $150 \mathrm{nmol}$ each of ATP, GTP and CTP, $15 \mathrm{nmol}$ of $\left[{ }^{3} \mathrm{H}\right]$ UTP $(500$ c.p.m. $/ \mathrm{pmol}$ ) and $50 \mu \mathrm{g}$ of rifamycin AF/013. The reaction was carried out at $37^{\circ} \mathrm{C}$ for $15 \mathrm{~min}$. In either case RNA synthesis was stopped by the addition of $0.15 \mathrm{ml}$ of $0.2 \mathrm{M}$-EDTA, pH7.9, and cooling at $0^{\circ} \mathrm{C}$. Bovine serum albumin $(150 \mu \mathrm{g})$ was added, followed by $5 \mathrm{ml}$ of cold $5 \%$ (w/v) trichloroacetic acid containing $0.01 \mathrm{M}$-sodium pyrophosphate. After standing for $30 \mathrm{~min}$ at $0^{\circ} \mathrm{C}$, the solution was centrifuged for $20 \mathrm{~min}$ at $2380 \mathrm{~g}$ in a Beckman model JS 7.5 rotor. The pellet was dissolved in $0.2 \mathrm{ml}$ of cold $0.2 \mathrm{M}-\mathrm{NaOH}$ and immediately reprecipitated with $5 \mathrm{ml}$ of cold $5 \%(\mathrm{w} / \mathrm{v})$ trichloroacetic acid. The precipitate was collected on glassfibre filters (934-AH; Reeve Angel, Clifton, NJ, U.S.A.) and washed with $30 \mathrm{ml}$ of the cold $5 \%$ trichloroacetic acid. The filters were dried and transferred to counting vials containing $4 \mathrm{ml}$ of scintillation fluid $[6 \mathrm{~g}$ of 2,5 -diphenyloxazole, $0.15 \mathrm{~g}$ of 1,4-bis-(5-phenyloxazol-2-yl)benzene/litre of toluene]. The radioactivity was determined in a Beckman model LS-250 liquid-scintillation spectrometer.

\section{Isolation of RNA}

After removal of the chromatin by centrifugation at $10000 \mathrm{~g}$ for $20 \mathrm{~min}$, the synthesized RNA was treated with $20 \mu \mathrm{g}$ of Proteinase $\mathrm{K} / \mathrm{ml}$ in an extraction buffer containing $0.5 \%(\mathrm{w} / \mathrm{v})$ sodium dodecyl sulphate, $0.01 \mathrm{M}-\mathrm{NaCl}, 0.01 \mathrm{M}-\mathrm{EDTA}$ and $0.01 \mathrm{M}$ sodium acetate, $\mathrm{pH} 5.0$, for $30 \mathrm{~min}$ at $37^{\circ} \mathrm{C}$. An equal volume of distilled phenol (saturated with extraction 
buffer)/chloroform $(1: 1, \mathrm{v} / \mathrm{v})$ was added, and the mixture was shaken at room temperature $\left(21^{\circ} \mathrm{C}\right)$ for $30 \mathrm{~min}$. After centrifugation at $10000 \mathrm{~g}$ for $10 \mathrm{~min}$, the aqueous phase was removed. Phenol and chloroform were added again and the operation was repeated until no protein interphase was observed. The aqueous fraction was removed and $50 \mu \mathrm{g}$ of purified tRNA was added as a carrier. The RNA was precipitated with $2.5 \mathrm{vol}$. of $95 \%$ ethanol at $-20^{\circ} \mathrm{C}$ for $18 \mathrm{~h}$. RNA was spun down at $4500 \mathrm{~g}$ for $15 \mathrm{~min}$ at $0^{\circ} \mathrm{C}$ in a Beckman model $\mathrm{JA} 20$ rotor and subsequently freeze-dried.

\section{Sucrose gradient centrifugation}

RNA (approx. 25000c.p.m.) obtained by the previous procedure was suspended in $0.1 \mathrm{ml}$ of glass-distilled water, heated at $70^{\circ} \mathrm{C}$ for $1 \mathrm{~min}$, cooled quickly, layered on top of a linear $5-20 \%(w / v)$ sucrose gradient $(4.9 \mathrm{ml})$, and centrifuged at $189000 \mathrm{~g}$ in a Beckman SW 50.1 rotor at $4^{\circ} \mathrm{C}$ for $2.5 \mathrm{~h}$. Twenty fractions $(0.15 \mathrm{ml} /$ fraction) were collected, and the amount of $5 \%$-trichloroacetic acid-precipitable radioactivity was determined. Purified cytoplasmic RNA (consisting of $28 \mathrm{~S}, 18 \mathrm{~S}$, and $4 \mathrm{~S}$ RNA from the hen oviduct) was used as a molecular-weight marker to standardize the gradients. The chain length of the synthesized RNA was determined as indicated by Spirin (1963) and Cedar \& Felsenfeld (1973).

\section{General procedures}

These were as cited in Mezquita \& Teng (1977).

\section{Results}

Titration of chromatin with E. coli and wheat-germ RNA polymerases

Chromatin prepared from nuclei at different stages of spermatogenesis was preincubated with increasing quantities of $E$. coli RNA polymerase for $15 \mathrm{~min}$ at $37^{\circ} \mathrm{C}$ (Tsai et al., 1975). RNA chain initiation was started by the addition of nucleotides, rifampicin and heparin, and RNA synthesis was allowed to occur for an additional period of $15 \mathrm{~min}$. Rifampicin at the concentration used allows initiation from the highly stable preinitiation complexes formed during the preincubation, but inhibits secondary initiation and reinitiations (Hinkle \& Chamberlin, 1972; Mangel \& Chamberlin, 1974). Heparin inhibits ribonuclease activity (Cox et al., 1973). The rifampicin-resistant RNA synthesis exhibited two phases in the chromatin prepared from nuclear stages 1 and 2 (Fig. 1). A gradual enhancement of RNA synthesis on addition of increasing quantities of polymerase $(0-16 \mu \mathrm{g})$ was followed by a very small increase in nucleotide incorporation with further increases in polymerase concentration $(16-30 \mu \mathrm{g})$.

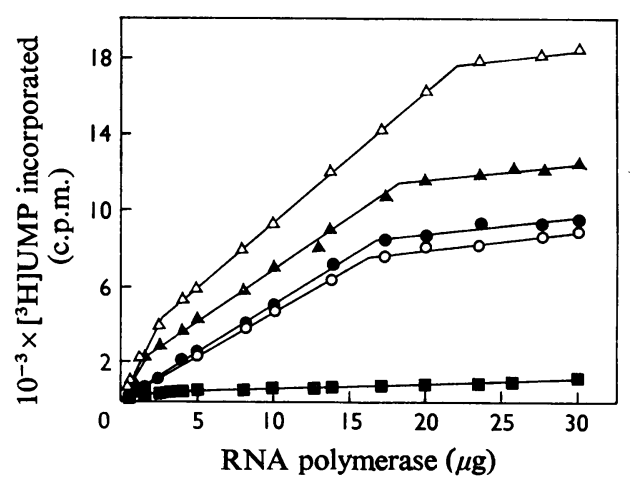

Fig. 1. E. coli RNA polymerase saturation curves on chromatin from different stages of spermatogenesis $E$. coli RNA polymerase $(0-30 \mu \mathrm{g})$ was preincubated with $5 \mu \mathrm{g}$ of chromatin at $37^{\circ} \mathrm{C}$ for $15 \mathrm{~min}$ in $0.2 \mathrm{ml}$ of preincubation mixture as described in the Materials and Methods section. After the preincubation, $50 \mu \mathrm{l}$ of nucleotides containing $10 \mu \mathrm{g}$ of rifampicin and $200 \mu \mathrm{g}$ of heparin was added and incubated at $37^{\circ} \mathrm{C}$ for an additional $15 \mathrm{~min}$. The RNA synthesized was precipitated with $5 \%(\mathrm{w} / \mathrm{v})$ trichloroacetic acid and counted for radioactivity as described in the Materials and Methods section. $\bullet$, Chromatin from stage 1; $O$, chromatin from stage $2 ; \mathbf{\Lambda}$, chromatin from stage 3 ; $\triangle$, chromatin from stage 4 ;, chromatin from stage 5 .

The titration curves of chromatin from nuclear stages 3 and 4 revealed three different phases of RNA synthesis (Fig. 1). Chromatin from stage-4 nuclei (elongated spermatids and testicular spermatozoa) showed an initial steep increase in RNA synthesis on addition of RNA polymerase ( $0-3 \mu \mathrm{g})$, followed by a second phase with a lower rate of increment in RNA synthesis (3-22 $\mu \mathrm{g}$ of RNA polymerase) in relation to the initial increase, and a third phase with very small increases in nucleotide incorporation with the additions of polymerase $(22-30 \mu \mathrm{g})$.

The titration curves of the chromatin from stage- 3 nuclei (round and elongating spermatids) showed three different phases in an intermediate position between the titration curves of chromatin from stage- 1 and stage- 4 nuclei. The titration curve of the chromatin from stage-5 nuclei (spermatozoa from the vas deferens) showed very small increments of nucleotide incorporation on addition of RNA polymerase $(0-30 \mu \mathrm{g})$.

For titration of the different types of chromatin with wheat-germ RNA polymerase II, the rifamycin derivative AF/013 was used instead of rifampicin (Meilhac et al., 1972). To compare the titration curves of the chromatin with $E$. coli RNA polymerase and wheat-germ RNA polymerase II, both enzymes were incubated with chromatin in the presence of rifamycin 

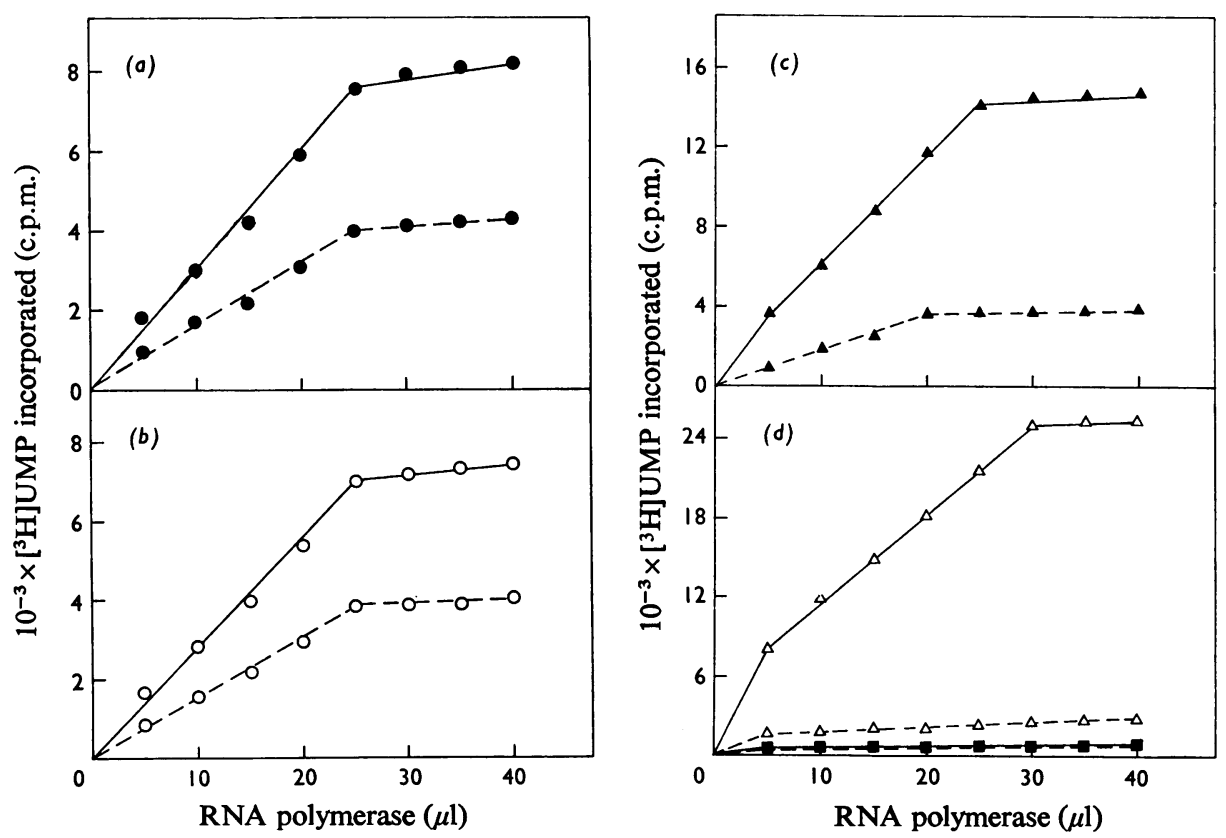

Fig. 2. E. coli and wheat-germ RNA polymerase saturation curves on chromatin from different stages of spermatogenesis $E$. coli RNA polymerase (-) and wheat-germ RNA polymerase (---) were preincubated with $5 \mu \mathrm{g}$ of chromatin at $37^{\circ} \mathrm{C}$ for $15 \mathrm{~min}$ in $0.2 \mathrm{ml}$ of preincubation mixture as described in the Materials and Methods section. Stock concentrations used were $0.4 \mu \mathrm{g} / \mu \mathrm{l}$ for $E$. coli RNA polymerase and $1 \mu \mathrm{g} / \mu \mathrm{l}$ for wheat-germ RNA polymerase. After the preincubation $50 \mu \mathrm{g}$ of nucleotides containing $50 \mu \mathrm{g}$ of rifamycin AF/013 was added and incubated at $37^{\circ} \mathrm{C}$ for an additional $15 \mathrm{~min}$. The RNA synthesized was precipitated with $5 \%(\mathrm{w} / \mathrm{v})$ trichloroacetic acid and counted for radioactivity. (a) $\bullet$, chromatin from stage $1 ;(b) \bigcirc$, chromatin from stage $2 ;(c) \Delta$, chromatin from stage $3 ;(d) \Delta$, chromatin from stage $4 ; \square$, chromatin from stage 5 .

$\mathrm{AF} / 013$ as described in the Materials and Methods section.

Using chromatin from the nuclei of stages 1 and 2, we obtained similar enzyme-saturation curves with the prokaryotic and the eukaryotic enzymes (Figs. $2 a$ and $2 b$ ). After a gradual increment in RNA synthesis on addition of RNA polymerase ( $0-25 \mu \mathrm{l})$, saturation was reached $(25-40 \mu \mathrm{l})$. At the saturation point the ratio of RNA synthesized by $E$. coli RNA polymerase to that by wheat-germ RNA polymerase II was 1.8:1. The titration curves obtained for chromatin from stage-4 nuclei with the prokaryotic and eukaryotic enzymes were clearly different (Fig. $2 d$ ). The titration with the $E$. coli enzyme revealed three different phases of RNA synthesis: an initial steep increase $(0-5 \mu 1$ of added enzyme), followed by a second phase with a lesser slope (5-30 $\mu$ l of enzyme), and then the saturation phase (30-40 $\mu 1$ of enzyme). With wheat-germ RNA polymerase II the saturation was reached after addition of a small quantity of the enzyme $(5 \mu \mathrm{l})$, and the ratio of RNA synthesis by the prokaryotic to that by the eukaryotic enzyme was $15: 1$ at the saturation point.
The titration curves of chromatin from stage 3 (Fig. 2c) showed characteristics between those of stages 1 and 4 . The titration with $E$. coli RNA polymerase revealed three different phases, as did the chromatin of stage- 4 nuclei. The saturation point with wheat-germ polymerase was reached with $20 \mu \mathrm{l}$ of enzyme, and the ratio of RNA synthesis by the prokaryotic to that by the eukaryotic enzyme was 3.7:1.

The titration curve of chromatin from spermatozoa showed very low increments in nucleotide incorporation with both RNA polymerases (Fig. $2 d$ ).

Determination of the number of RNA initiation sites for E. coli RNA polymerase on chromatin

The number of RNA initiation sites on the chromatin was determined by the following equation (Tsai et al., 1975):

Number of initiation sites

$$
\begin{aligned}
\text { pg of DNA } & \text { c.p.m. } \times 10^{-12} \times 4 \times N \\
= & \frac{\text { sp. radioact. } \times \text { DNA } \times \text { size }}{}
\end{aligned}
$$


where c.p.m. is c.p.m. of UMP incorporated at transition point (RNA polymerase saturation point on chromatin); $N$ is Avogadro's number; sp. radioact. is specific radioactivity of $\left[{ }^{3} \mathrm{H}\right] \mathrm{UTP}$ (75c.p.m./ pmol); DNA is amount of chromatin DNA used (pg); size is number of nucleotides in the average chain length of RNA.

A sucrose-gradient analysis of RNA synthesized on chromatin from various stages of nuclei in vitro in the presence of rifampicin and heparin is presented in Fig. 3. According to the radioactivity profile and from Spirin's (1963) equation, the average lengths of the RNA chains were calculated to be $754,764,730$, 823 and 508 nucleotides/chain for the respective chromatin stages $1,2,3,4$ and 5 (Table 1).

The initiation sites (in terms of $10^{-4} \times$ sites/pg of

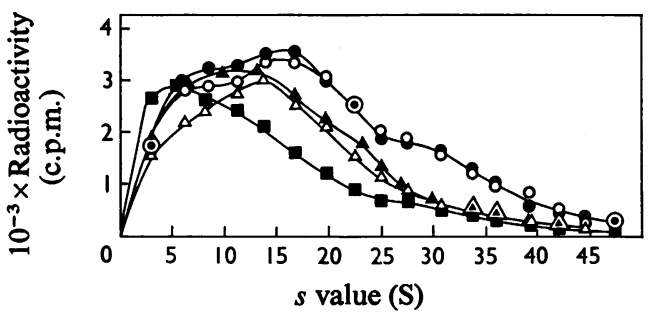

Fig. 3. Sucrose-gradient analysis of RNA synthesized on chromatin in vitro

Chromatin ( $25 \mu \mathrm{g}$ of DNA, except $50 \mu \mathrm{g}$ for spermatozoal chromatin) from various spermatogenic nuclei was incubated with $20 \mu \mathrm{g}$ of $E$. coli RNA polymerase for $15 \mathrm{~min}$ at $37^{\circ} \mathrm{C}$. The conditions for RNA synthesis, extraction and sucrose-gradient centrifugation were described in the Materials and Methods section. The symbols representing the stage of spermatogenesis are as in Fig. 1.

Table 1. RNA-chain-initiation sites and $R N A$ chain length on chromatin at different stages of spermatogenesis The procedures for chromatin preparation, RNA synthesis, RNA product analysis on sucrose gradient, RNA chain initiation sites and chain-length determination were described in the Materials and Methods section.

$$
10^{-4} \times
$$

No. of initiation Size of RNA

Stage of sites/pg of synthesized

differentiation chromatinDNA (nucleotides)

$\begin{array}{lrl}1 & 7.16 & 754 \\ 2 & 6.40 & 764 \\ 3 & 10.04 & 730 \\ 4 & 13.83 & 823 \\ 5 & 0.44 & 508\end{array}$

DNA) were calculated as $7.16,6.40,10.04,13.83$ and 0.44 for the chromatin of stages $1,2,3,4$ and 5 respectively (Table 1$)$.

\section{Rates of $R N A$ chain elongation}

The propagation rates of the RNA chains were measured by preincubating $E$. coli RNA polymerase with different chromatins for $15 \mathrm{~min}$ at $37^{\circ} \mathrm{C}$. Chain initiation and elongation were started by the addition of the four nucleoside triphosphates, rifampicin and heparin. After 1, 2, 3 and $15 \mathrm{~min}$ of incubation the rate of RNA chain elongation was estimated by dividing the initial rate of RNA synthesis by the total number of RNA chains synthesized, calculated as described above. The initial rates of elongation were $86,89,98$ and 167 nucleotides/min for stages $1,2,3$ and 4 respectively.

Kinetics of formation of stable binary complexes between $E$. coli $R N A$ polymerase and chromatin

The processes of formation of the binary complex between RNA polymerase and its binding sites on DNA, as originally proposed by Chamberlin (1974), consisted of three steps: (1) the dissociation of polymerase from the non-specific sites, (2) the binding of polymerase to the initiation sites and the formation of a preinitiation complex (I complex), and (3) the formation of a stable complex (RS complex) on the initiation sites for initiating RNA synthesis.

Chromatin from nuclei at different stages of spermatogenesis was preincubated for various lengths of time to allow the formation of RS complexes capable of rapidly initiating RNA synthesis. The amount of RS complex formed was assayed by measuring RNA synthesis after the simultaneous addition of nucleotides and rifampicin. The formation of RS complexes on the chromatin of stages 1 and 2 reached a maximum after $40 \mathrm{~min}$ of preincubation, whereas on the chromatin of stages 3,4 and 5 , the preincubation times required to reach a maximum were 30,15 and $10 \mathrm{~min}$ respectively (Figs. $4 a-4 d$ ).

The semilogarithmic plots of the maximum rate of RNA synthesis minus the rate of RNA synthesis at each preincubation time versus the time of preincubation were linear for the chromatin of different stages (insets for Fig. 4). The half-time of formation of the RS complex $\left(t_{t}\right)$ at $37^{\circ} \mathrm{C}$ was $9.5 \mathrm{~min}$ for stage- 1 and -2 chromatin, and decreased to $7.5,5.5$ and $2.0 \mathrm{~min}$ for the chromatin of stages 3,4 and 5 respectively (Table 2 ).

To test the possibility of artificial modification of the chromatin during preincubation, chromatin was incubated without RNA polymerase for various lengths of time. The pretreated chromatin was preincubated for $15 \mathrm{~min}$ with RNA polymerase, and the amount of the RS complex formed was measured as before. The amount of RNA synthesized was constant 

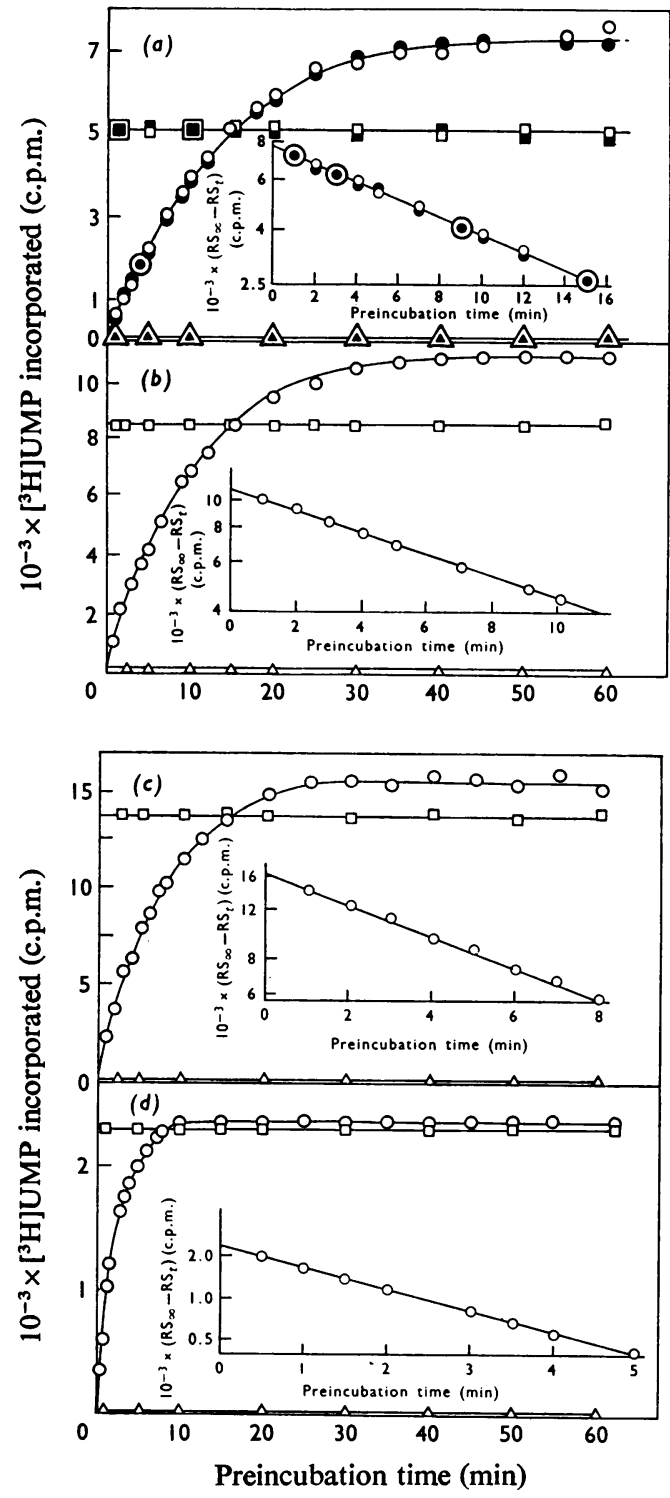

Fig. 4. Time course of formation of stable binary complex Chromatin was prepared from the nuclei of $(a)$ stages 1 and 2, (b) stage 3, (c) stage 4 and $(d)$ stage 5. Chromatin $(5 \mu \mathrm{g}$ of DNA, except $15 \mu \mathrm{g}$ of DNA for spermatozoal chromatin) from different stages of spermatogenesis were preincubated according to the following conditions: $O$, chromatin was preincubated with $20 \mu \mathrm{g}$ of $E$. coli RNA polymerase; $\Delta$, chromatin was preincubated without the addition of $E$. coli RNA polymerase for the indicated time intervals; $\square$, chromatin was incubated at $37^{\circ} \mathrm{C}$ without the presence of $E$. coli RNA polymerase for the indicated time intervals, then followed by the addition of $20 \mu \mathrm{g}$ of enzyme and incubated for an additional $15 \mathrm{~min}$. After the preincubation, RNA synthesis was initiated by the addition of $0.05 \mathrm{ml}$ of ribonucleoside triphos-
Table 2. Effect of temperature on the formation of stable binary complex

The value of $t_{+}$and the ratio of $\mathrm{RS}_{\max }$. was determined as shown in Fig. 3.

\begin{tabular}{|c|c|c|c|}
\hline \multirow{2}{*}{$\begin{array}{c}\text { Stage of } \\
\text { differentiation }\end{array}$} & \multicolumn{2}{|c|}{$t_{\ddagger}(\min )$} & \multirow{2}{*}{$\begin{array}{l}\text { Ratio of RS } \\
\quad\left(37^{\circ} / 0^{\circ} \mathrm{C}\right)\end{array}$} \\
\hline & $37^{\circ} \mathrm{C}$ & $0^{\circ} \mathrm{C}$ & \\
\hline 1 & 9.5 & 10.0 & 3.6 \\
\hline 2 & 9.5 & 10.0 & 3.6 \\
\hline 3 & 7.5 & 13.5 & 6.5 \\
\hline 4 & 5.5 & 20.0 & 10.0 \\
\hline 5 & 2.0 & 22.0 & 10.0 \\
\hline
\end{tabular}

for chromatin pretreated for periods of up to $60 \mathrm{~min}$; the same amount was obtained with chromatin preincubated for $15 \mathrm{~min}$ with RNA polymerase without previous pretreatment (Fig. 4).

To rule out the possibility that the rifampicinresistant RNA synthesis might be produced by the endogenous RNA polymerase, we examined RNA synthesis in the absence of added exogenous RNA polymerase. There was no detectable RNA synthesis under this condition (Fig. 4). Evidently, then, endogenous RNA polymerase activity does not contribute to the total RNA synthesis.

\section{Effect of temperature on RS-complex formation}

During the processes of RS-complex formation in DNA, temperature is a critical factor; it accelerates the transformation of I complex into RS complex. This is a rate-limiting step of conversion. The $t_{t}$ for RS-complex formation measured at $0^{\circ} \mathrm{C}$ is therefore higher than that at $37^{\circ} \mathrm{C}$ (Mangel \& Chamberlin, 1974).

In contrast, the formation of RS complex in chromatin is less dependent on temperature than in DNA, and is more dependent on the chromosomal proteins (Hirose et al., 1976). An investigation of the effect of the preincubation temperature on RScomplex formation in the chromatin of various stages of spermatogenic nuclei could reveal more about the structure of chromatin in the initiating site region.

The $t_{t}$ of RS-complex formation of different types of chromatin was determined at two different preincubation temperatures $\left(37\right.$ and $\left.0^{\circ} \mathrm{C}\right)$. Results presented in Table 2 indicate that RS-complex formation in chromatin of stages 1 and 2 has a low temperature-dependence. The $t_{\frac{1}{2}}$ for RS-complex

phate mixture containing $0.2 \mathrm{mg}$ of rifampicin $/ \mathrm{ml}$. RNA was synthesized at $37^{\circ} \mathrm{C}$ for $15 \mathrm{~min}$. In (a) the solid symbol represents stage-1 chromatin, and the empty symbol represents stage-2 chromatin. 
formation measured at $0^{\circ} \mathrm{C}$ compared with that at $37^{\circ} \mathrm{C}$ showed no significant increase (from 9.5 to $10 \mathrm{~min}$ ). However, a high temperature-dependence was observed in the chromatin of stages 4 and 5 . The $t_{1}$ for RS-complex formation increased from 5.5 to $20 \mathrm{~min}$ for stage 4 , and from 2 to $22 \mathrm{~min}$ for stage 5 . Stage-3 chromatin showed a temperature-dependence intermediate between that of stage 2 and stage 4; the $t_{*}$ measured at $0^{\circ} \mathrm{C}$ is $13.5 \mathrm{~min}$ and that at $37^{\circ} \mathrm{C}$ is $7.5 \mathrm{~min}$.

Correspondingly, the ratio of maximal RScomplex formation at $37^{\circ} \mathrm{C}$ to that at $0^{\circ} \mathrm{C}$ in stage- 1 and -2 chromatin showed less temperature-dependence than that of stages 4 and 5 .

Temperature-dependence of RNA synthesis by wheatgerm RNA polymerase

RNA synthesis on chromatin of meiotic nuclei showed low temperature-dependence. Meiotic chromatin $(5 \mu \mathrm{g})$ was preincubated with wheat-germ polymerase II $(20 \mu \mathrm{g})$ at $37^{\circ} \mathrm{C}$ and $0^{\circ} \mathrm{C}$ for $40 \mathrm{~min}$. RNA synthesis was initiated by the addition of nucleotides and rifamycin AF/013 under the conditions described in the Materials and Methods section. The ratio of RNA synthesized after $15 \mathrm{~min}$ at $37^{\circ} \mathrm{C}$ to that at $0^{\circ} \mathrm{C}$ was $2.6: 1$. In contrast, chromatin from elongated spermatids showed a higher temperature-dependence, with a ratio of $5: 1$.

\section{Discussion}

The different patterns of initiation of RNA synthesis in vitro observed in chromatin from nuclei at various stages of spermatogenesis could be explained by the changes that chromosomal proteins undergo during the differentiation process.

Meiotic and premeiotic nuclei possess chromatin with somatic histones and a heterogeneous population of non-histone proteins (Platz et al., 1975; Mezquita \& Teng, 1977). The initiation pattern of RNA synthesis in vitro of chromatin from such nuclei by either the E. coli RNA polymerase or the wheatgerm RNA polymerase II is comparable with that reported by Tsai et al. $(1976 a, b)$ and Hirose $e t$ al. (1976) for chromatin of somatic cells.

In elongated spermatids the non-histone proteins decrease greatly (Vaughn, 1966; Zirkin, 1970; Mezquita, 1974; Platz et al., 1975; Mezquita \& Teng, 1977), and the histones are acetylated, removed, and replaced by phosphorylated protamines (Candido \& Dixon, 1972; Louie et al., 1974; Grimes et al., 1975; Marushige \& Marushige, 1975; Marushige et al., 1976). These changes could alter the basic structure of the chromatin and be responsible for both the increase in initiation sites and the type of initiation pattern observed in elongated spermatids.

The initiation pattern of RNA synthesis in vitro obtained on native DNA by using $E$. coli RNA polymerase differs from the pattern observed on chromatin in the following ways: (1) increased number of binding sites (Cedar \& Felsenfeld, 1973; Tsai et al., 1975); (2) increased rate of propagation of growing RNA chains (Cedar \& Felsenfeld, 1973); (3) presence of strong and weak polymerase-binding sites (Tsai et al., 1975); (4) shorter half-time of formation of high-affinity enzyme-chromatin complexes (RS complexes) and a higher temperaturedependence of the RS-complex formation (Hirose et al., 1976; Tsai et al., 1976b). The eukaryotic RNA polymerase II enzyme is far less efficient for initiation of RNA synthesis on intact double-stranded DNA than is the prokaryotic enzyme (Meilhac \& Chambon, 1973). The eukaryotic enzyme also shows higher temperature-dependence for RNA synthesis with native DNA than with chromatin (Tsai et al., 1976b).

All the characteristics of the initiation pattern of RNA synthesis in vitro on chromatin from elongated spermatids reported in the present paper are similar to those of intact double-stranded DNA described above. This fact and our previous finding of a high capacity for binding of actinomycin $\mathbf{D}$ in elongated spermatids (Mezquita \& Teng, 1977) indicate that unmasked stable double-stranded DNA is present in the chromatin of the elongated spermatids during the transition from nucleohistone to nucleoprotamine in rooster spermatogenesis.

Finally, in spermatozoa the massive condensation of the chromatin by a highly basic protein renders the DNA inaccessible to RNA polymerase (Marushige \& Dixon, 1969; Shih \& Bonner, 1970; Subirana, 1975; Mezquita \& Teng, 1977), causing the great decrease in the number of initiation sites reported here.

We thank Dr. G. Lancini for providing rifamycin AF/013, and Mr. R. Downing and Miss M. Flowers for assistance. This study was supported by National Institutes of Health grant HD-08218 and in part by grant AG-00523. C. M. was supported by a fellowship from Ministerio Espan̆ol de Educación y Ciencia.

\section{References}

Barcellona, W. J., Brackeen, R. B. \& Brinkley, B. R. (1974) J. Reprod. Fertil. 39, 41-48

Burgess, R. R. \& Jendrisak, J. J. (1975) Biochemistry 14, 4634-4638

Candido, E. P. M. \& Dixon, G. H. (1972) J. Biol. Chem. 247, 5506-5510

Cedar, H. \& Felsenfeld, G. (1973) J. Mol. Biol. 77, 237-254

Chamberlin, M. J. (1974) Annu. Rev. Biochem. 43, 721-775

Chevaillier, P. \& Gusse, M. (1975) J. Microsc. Biol. Cell. 23, 153-164

Cox, R., Hines, M. \& Carey, N. (1973) Eur. J. Biochem. 32, 513-524

Darżynkiewicz, Z., Bolund, L. \& Ringertz, N. R. (1969) Exp. Cell Res. 55, 120-123 
Grimes, S. R., Chae, C. B. \& Irvin, J. L. (1975) Arch. Biochem. Biophys. 168, 425-435

Hinkle, D. C. \& Chamberlin, M. J. (1972) J. Mol. Biol. 70, 157-185

Hirose, M., Tsai, M. J. \& O'Malley, B. W. (1976) J. Biol. Chem. 251, 1137-1146

Honda, B. M., Baillie, D. L. \& Candido, E. P. M. (1974) FEBS Lett. 48, 156-159

Jendrisak, J. J. \& Burgess, R. R. (1975) Biochemistry 14, 4639-4645

Kierszenbaum, A. L. \& Tres, L. L. (1975) J. Cell Biol. 65, 258-270

Lison, L. (1955) Acta Histochem. 2, 47-67

Loir, M. (1972) Ann. Biol. Anim. Biochem. Biophys. 12, $411-429$

Loir, M. \& Hochereau de Reviers, M. T. (1972) J. Reprod. Fertil. 31, 127-130

Louie, A. J., Candido, E. P. M. \& Dixon, G. H. (1974) Cold Spring Harbor Symp. Quant. Biol. 38, 803-819

Mangel, W. F., \& Chamberlin, M. J. (1974) J. Biol. Chem. 249, 2995-3001

Marushige, K. \& Dixon, G. H. (1969) Dev. Biol. 19, 397-414

Marushige, K., Marushige, Y. \& Wong, T. K. (1976) Biochemistry 15, 2047-2053

Marushige, Y. M. \& Marushige, K. (1975) J. Biol. Chem. 250, 39-45

Meilhac, M. \& Chambon, P. (1973) Eur. J. Biochem. 35, 454-463

Meilhac, M., Tysper, Z. \& Chambon, P. (1972) Eur. J. Biochem. 28, 291-300
Mezquita, C. (1974) M.D. Thesis, University of Barcelona Mezquita, C. \& Teng, C. S. (1977) Biochem. J. 164, 99-111 Monesi, V. (1964) J. Cell Biol. 22, 521-532

Olins, D. E., Olins, A. L. \& Von Hippel, P. H. (1968) J. Mol. Biol. 33, 265-281

Platz, R. D., Grimes, S. R., Meistrich, M. L. \& Hnilica, L. S. (1975) J. Biol. Chem. 250, 5791-5850

Premkumar, E. \& Bhargava, P. M. (1972) Nature (London) New Biol. 240, 139-143

Schwartz, R. J., Tsai, M. J., Tsai, S. Y. \& O'Malley, B. W. (1975) J. Biol. Chem. 250, 5175-5182

Shih, T. Y. \& Bonner, J. (1970) J. Mol. Biol. 50, 333-344

Sippel, A. \& Hartmann, G. R. (1970) Eur. J. Biochem. 16, 152-157

Spirin, A. (1963) Prog. Nucleic Acid Res. 1, 301-346

Subirana, J. A. (1975) Biol. J. Linn. Soc. 7, Suppl. 1, 239-244

Tingari, M. D. (1973) J. Reprod. Fertil. 34, 255-265

Tsai, M. J., Schwartz, R. J., Tsai, S. Y. \& O'Malley, B. W. (1975) J. Biol. Chem. 250, 5165-5174

Tsai, M. J., Towle, H. C., Harris, S. E. \& O'Malley, B. W. (1976a) J. Biol. Chem. 251, 1960-1969

Tsai, M. J., Tsai, S. Y., Towle, H. C. \& O'Malley, B. W. (1976b) J. Biol. Chem. 251, 5565-5574

Vaughn, J. C. (1966) J. Cell Biol. 31, 257-278

Walker, M. H. (1971) Chromosoma 34, 340-354

Yamamoto, K. R. \& Alberts, B. M. (1976) Annu. Rev. Biochem. 45, 721-746

Zirkin, B. R. (1970) Chromosoma 31, 231-240 